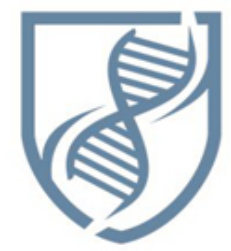

Journal of Bioscience and Applied Research

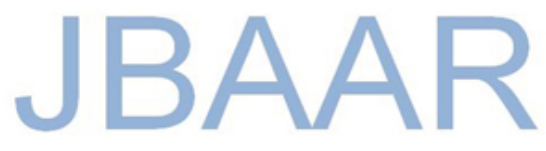

WWW.JBAAR.ORG

\title{
Ameliorative effect of ginger extract against pathological alterations induced in mice bearing solid tumors
}

\author{
Osama M. Badr ${ }^{1}$, Saber A. Sakr² ${ }^{2}$, Hala M. Abd-Eltawab ${ }^{1}$ \\ ${ }^{1}$ Animal Biotechnology Department, Genetic Engineering \& Biotechnology Institute, \\ Sadat City University, Sadat City, Menoufia Province, Egypt. \\ ${ }^{2}$ Zoology Department, Faculty of Science, \\ Menoufia University, Shebin Elkom, Menoufia Province, Egypt. \\ (Corresponding author Email: osama.badr@gebri.usc.edu.eg)
}

\begin{abstract}
This study was prepared to explore the effect of ginger extract in defeating the Ehrlich Ascites Carcinoma (EAC) injected subcutaneously in mice and induced solid tumour. After the solid tumour formation; the mice were classified into four groups (control, tumour untreated, ginger and ginger \& tumour). Eight mice were grouped separately in each cage. Mice were killed and dissected at the end of this investigation; liver and kidney were removed for histopathological study. The biochemical parameters (ALT, AST, Urea, Creatinine, MDA, SOD and CAT) were measured in the sera of all tested groups. Ginger extract ameliorated the histological structures of both liver and kidney to be near to control, modulated the elevated values of (ALT, AST, Urea, Creatinine and MDA) and reduced values of (SOD and CAT) to record slightly normal readings. Tumour volumes reduced significantly and the destructed genomic DNA retained the normal pattern. Ginger has no pathological effects on control mice.

Keywords: Biochemistry, DNA pattern, ginger, kidney, liver, mice, solid tumour.
\end{abstract}

\section{Introduction}

The influence of plant extracts as antitumor was investigated due to their low toxicity and side effects to normal cells in compared to chemotherapy and irradiation therapy; Thousands of herbal and traditional compounds are being screened worldwide to validate their use as anticancerous drugs (Diwanay et al., 2004). Ginger (Zingiber officinale) belongs to the family Zingiberaceae which is widely used as a spice or a traditional medicine. Several studies have been done to prove that ginger extract could be effective against many types of cancer. Extracts of the spice ginger are affluent in gingerols and shogaols, which exhibit antioxidant, anti-inflammatory and anticarcinogenic proprieties under "in vitro", and "in vivo" systems (Surh, 2002; Yogeshwer and Madhulika, 2007). It was stated that the ginger extract has a preventive properties against cancer because of the potent activity of its constituents; polyphenolic and flavonoid compounds (Shukla et al., 2007). Kundu et al. (2009) mentioned that ginger has the ability to defeat cancer in vivo and in vitro studies. Sahdeo and Amit (2015) suggested that ginger and its active ingredients have the ability to defeat the growth and induce apoptosis of different types in cancer from in vitro and animal studies. Ginger extract has antioxidative features that can sweep the superoxide anion and hydroxyl radicals. It can block the activity of peroxidation (Topic et al., 2002).

Ehrlich ascites carcinoma (EAC) is one of the public experimental tumors. It appeared mainly as an impulsive breast cancer in a female mouse (Aktas, 1996; Taskin, 2002), and then Ehrlich and Apolant (1905) used it as an experimental tumor by transporting the tumor cells subcutaneously from 
mouse to mouse. Loewenthal and Jahn (1932) obtained the liquid form in the peritoneal cavity of the mouse and named it as "Ehrlich ascites carcinoma" due to the ascites liquid, together with the carcinoma cells.

Reactive oxygen species (ROS), such as superoxide anions and hydrogen peroxide stimulated lipid peroxidation, perform a vital part in malignant conversion and tumor cell propagation and infestation (Tatiane et al., 2009). Surplus oxidative species can directly destruct DNA, proteins and lipids. Antioxidants can be grouped to two orders; enzymatic and non-enzymatic. The enzymatic system comprises enzymes formed by the organism itself, as superoxide dismutase (SOD), catalase (CAT). The enzyme SOD performs as a protection against superoxide, while the enzyme catalase act on $\mathrm{H}_{2} \mathrm{O}_{2}$ (Mahadik and Scheffer, 1996).

Most anti-cancer agents eradicate tumor cells by the induction of apoptosis (Fouda, 2005). Doaa et al., (2015) reported that grape skin and seeds treated animals exhibited in vivo hepatoprotective and antioxidant effects against liver injury induced by Ehrlich solid tumor growth.

The present investigation was carried out to evaluate the antitumor and antioxidant activity of ginger extract against different pathological effects induced by Ehrlich solid tumor growth in liver and kidney; biochemically and histologically. In addition to studying DNA fragmentation.

\section{Materials and Methods}

\section{Animals}

Thirty two Swiss albino female mice (20-25 g weight) obtained from the Animal House of the National cancer Institute, Cairo, Egypt, were used in the present study. The animals were randomized and kept under ambient room- temperature and relative humidity conditions, a commercial diet and water were provided ad libitum. The experiments were accepted by the state authorities and it followed the Egyptian rules on animal protection, as well as specific local institutional laws for protection of animals under the supervision of authorized examiners

\section{Experimental design}

The animals were randomly assigned into four experimental groups which were classified as follows: First group ( $\mathrm{n}=8$ mice) in which the mice were served as a control group. Second group ( $\mathrm{n}=8$ mice) in which the mice were injected subcutaneously with $0.2 \mathrm{ml}$ of Ehrlich ascites carcinoma (EAC) which contains $3 \times 10^{6}$ cells. Third group ( $\mathrm{n}=8$ mice) mice was treated orally with $0.1 \mathrm{ml}$ ginger extract in a dose (120 mg/ kg body weight) three times weekly for a month. Fourth group ( $\mathrm{n}=8$ mice) in which the mice were inoculated with (EAC) as in group 2 then treated orally with the ginger extract after 10 days of inoculation in a dose $(120 \mathrm{mg} / \mathrm{kg}$ body weight) three times weekly for a month.

\section{Ginger extraction}

Ginger (Zingiber officinale) was purchased from local markets, Cairo City, Egypt. A dried powder (10 g) from ginger was mixed with $100 \mathrm{ml}$ organic solvent (ethanol, hexane and ethyl acetate). The mixture was placed at room temperature for $24 \mathrm{~h}$ on shaker with $150 \mathrm{rpm}$. Solution was filtered through muslin cloth and then re-filtered by passing through Whatman Filter No. 1. The filtrate thus obtained was concentrated by complete evaporation of solvent at room temperature to yield the pure extract. Stock solutions of crude extract were prepared by mixing well the appropriate amount of dried ginger extract with respective solvent to obtain a final concentration of $100 \mathrm{mg} / \mathrm{ml}$. The solution was stored at $4^{\circ} \mathrm{C}$ after collecting in sterilized bottles until further use (Purshotam and Pankaj, 2011).

\section{Induction of solid tumor}

Ehrlich ascites carcinoma (EAC) cells collected from donor mice (Swiss albino) of 20-25 g body weight suspended in a sterile isotonic saline. A fixed number of viable cells (usually $3 \times 10^{6}$ cells/20 g body weight) were injected subcutaneously to the right hind limb of the mice (Gothoskar \& Ranadive, 1971). Solid tumors were induced after 10 days of inoculation.

\section{Determination of solid tumor volume}

Antitumor effect of ginger was evaluated by tumor growth inhibition. Tumors were measured individually using a Vernier caliper at 5 days intervals for one month starting with 15th day. Tumor volume was determined by the following formula: Tumor Volume $=$ length $\times$ width $^{2} \times 0.52$ (Jia et al., 2005).

\section{In vitro study}

Cytotoxicity assay of ginger extract on Ehrlich ascites tumor cells and cell viability test were measured microscopically by calculating the viability of tumor cells. The optimal concentration of ginger extract was estimated (120 mg/kg body weight). The viability percentage of tumor cells was measured after incubation with the ginger extract. According to (ElMerzabani et al., 1979); with some required 
modifications, the viability percentage of tumor cells were measured after incubation with the examined extract (ginger). The cell suspension was mixed with an equal volume of trypan blue $(4 \mathrm{mg} / \mathrm{ml})$ in the ratio 1:1 and incubated for $5 \mathrm{~min}$ at $37^{\circ} \mathrm{C}$. The estimation of the total number of viable cells was done using hemocytometer chamber (Hashim et al., 2014). Percentage of viable cells were calculated by the formula, Percentage viable cells $=[1.00-($ Number of trypan blue stained cells / Total cells) $\times 100$. The viability of the cells was $99 \%$ as judged by trypan blue exclusion assay.

\section{Histopathological examination}

The treated animals and their controls were killed by cervical dislocation, quickly dissected; liver and kidney were removed and fixed in Bouin's fluid. After $24 \mathrm{~h}$, tissues were rinsed three times in $70 \%$ ethanol, dehydrated using a graded ethanol series and then embedded in paraffin wax. Paraffin sections were cut into 5 micrometers thick slices and stained with haematoxylin and eosin for light microscope examination. The sections were viewed and photographed (Banchroft et al., 1996).

\section{DNA fragmentation assay}

DNA fragmentation assay by agarose gel electrophoresis in all tested groups was determined by the method described by (Tayeb and William, 1999). The total genomic DNA was isolated from mice tumor, liver and kidney belonging to different groups; by using a DNA extraction kit (TIANamp Genomic DNA Kit) and analyzed by electrophoresis on $1.5 \%$ agarose gel containing $0.1 \mathrm{mg} / \mathrm{ml}$ ethidium bromide and visualized under an UV illuminator.

\section{Biochemical analysis}

For enzymes determination, blood samples were collected from animals after 4 weeks of treatment. Sera were obtained by centrifugation of the blood sample and stored at $-20^{\circ} \mathrm{C}$ until assayed for the biochemical parameters. Both alanine aminotransferase and aspartate aminotransferase (ALT and AST); liver functions and plasma urea and creatinine (kidney functions) were determined colorimetrically using test reagent kits (Mediserve Company; Egypt for liver enzymes and Randox; UK for kidney functions), according to the manufacturer's instructions.

According to (Draper and Hadley 1990) the levels of lipid peroxidation product MDA (malondialdhyde) was estimated using the thiobarbituric acid (TBA) assay based on the release of color complex due to
TBA reaction with MDA. Catalase (CAT) activity was defined by the assay based on the rate of a hydrogen peroxide/ammonium molybdate complex formation (Gonenc et al., 2006). The activity of Superoxide dismutase (SOD) was determined according to the method of (Woolliams et al., 1983) which is based on the inhibition of nitroblue tetrazolium (NBT) reduction by the xanthine xanthine oxidase system as a superoxide generator.

\section{Statistical analysis}

The results were expressed as mean \pm SD of different groups. The differences between the mean values were evaluated by one way analysis of variance ANOVA followed by Tukey-Kramer multiple comparison test (Armitage and Berry, 1987) using Graph Pad Prism software. $P$ values $<0.05$ were considered to be statistically significant.

\section{Results}

\section{Tumor size:}

Measurements of the tumor size in mice EAC-bearing tumor and ginger-tumor mice; showed that ginger extract reduced the tumor volume in a very extremely significant way $(\mathrm{p}<0.0001)$. (Table 1$)$.

Table 1. Effect of ginger extract on tumor volume.

\begin{tabular}{|c|c|}
\hline Groups & Tumor Volume $\left(\mathbf{m m}^{3}\right)$ \\
& Mean \pm SD \\
\hline Tumor Untreated & $2.37 \pm \mathbf{0 . 1 9 4 9}$ \\
\hline Tumor treated with ginger & $\mathbf{1 . 0 8 2} \pm \mathbf{0 . 1 2 6 6}$ \\
\hline
\end{tabular}

$(* * * *)$ Very Extremely Significant $(\mathrm{p}<0.0001)$ compared to tumor untreated group.

\section{In vitro antitumor activity of ginger on EAC:}

The Ehrlich ascites carcinoma cells appear bright (not colored) and intact in Fig.1 (A); the viability of EAC was very high (Tumor-Untreated). On the other hand, in Fig.1 (B), Ehrlich ascites carcinoma cells treated with ginger appears to be colored with trypan blue. Animals bearing EAC cells treated with ginger showed a significant decrease in the total viable EAC cell count in comparison to non-treated tumor bearing animals. 

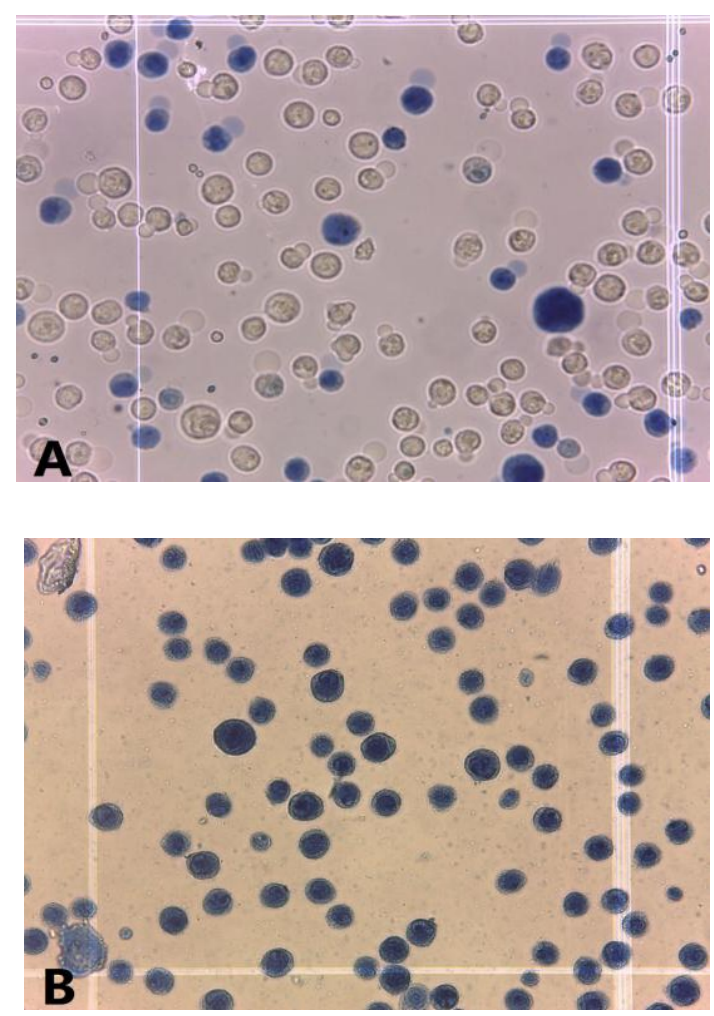

Figure 1. Photomicrograph showing (EAC) without treatment (A) and (EAC) treated with ginger (B). $\mathbf{X}$ 400

\section{Histological results:}

\section{A- Liver}

The control mice showed the normal structure of liver .The liver was formed from polygonal lobules. The outlines of the lobules were indistinct. The hepatocytes were polyhedral in shape, had vesicular spherical nuclei with prominent nucleoli and eosinophilic cytoplasm. The hepatocytes were arranged in cords that radiated out from the center of each lobule where the central vein situated. Between these hepatic cords were the hepatic sinusoids, the hepatic sinusoids are localized in between the cords and contained fine arrangement of Kupffer cells (Fig. 2A).

Experimental Ehrlich ascites bearing mice revealed massive pathological alterations distributed throughout the hepatic tissue. The liver showed enlarged and congested central vein, numerous focal lesions of leukocyte infiltration. Cytoplasmic vacuolar degenerations was also obvious in the hepatocytes. Kupffer cells were abundant more than normal (Figs. 2B, C and D). Infiltration of tumor cells mixed with leukocytes is a sign of tumor metastasis in liver tissue as shown in (Fig. 2B).

Examination of liver sections obtained from mice treated with ginger extract showing normal liver structure. While, the liver structure of mice treated with ginger extracts after solid tumor formation revealed some ameliorations but the central vein was still congested and enlarged (Fig.2 E, F).

\section{B- Kidney}

The kidney of a control mouse is composed of two main regions; the renal cortex and medulla which possess normal histological features. The renal cortex enclosed by numerous renal corpuscles, each made up of a glomeruli and the Bowman's capsule. There is a characteristic normal space between the glomeruli and Bowman's capsule to allow renal filtration. The renal corpuscles are surrounded by proximal and distal convoluted tubules. The tubules have inner wide luminal space lined externally with cuboidal epithelium; this is represented in (Fig. 3A).

Mice treated with EAC revealed marked damage of renal tissues; which are represented in degenerated renal tubules and glomerular atrophy; this is exhibited in (Fig. 3B). Leucocytic infiltration (LI) and degenerated renal tubules were also shown in (Fig. 3C). Proteinaceous casts in the lumen of the renal tubules were observed (Fig 3D).

Mice received ginger extract revealed that there is no pathological effects on the renal tissue and the histological structure of kidney appeared normal (Fig. 3E). In experimental Ehrlich ascites carcinoma treated with ginger, there was a marked amelioration of the histological structure of the kidney. This obvious in (Fig. 3F).

\section{DNA Fragmentation:}

DNA isolated from tumor, liver and kidney tissues of mice treated with EAC showed completely degradation into oligonucleotide fragments forming a clear laddering pattern of apoptosis when separated by agarose gel electrophoresis; as shown in Fig. (4). On the other hand, DNA patterns of tumor, liver and kidney tissues of mice treated with ginger during experimentation showed a normal pattern as shown in control. The genomic DNA in EAC bearing mice treated with ginger showed highly amelioration effects. 

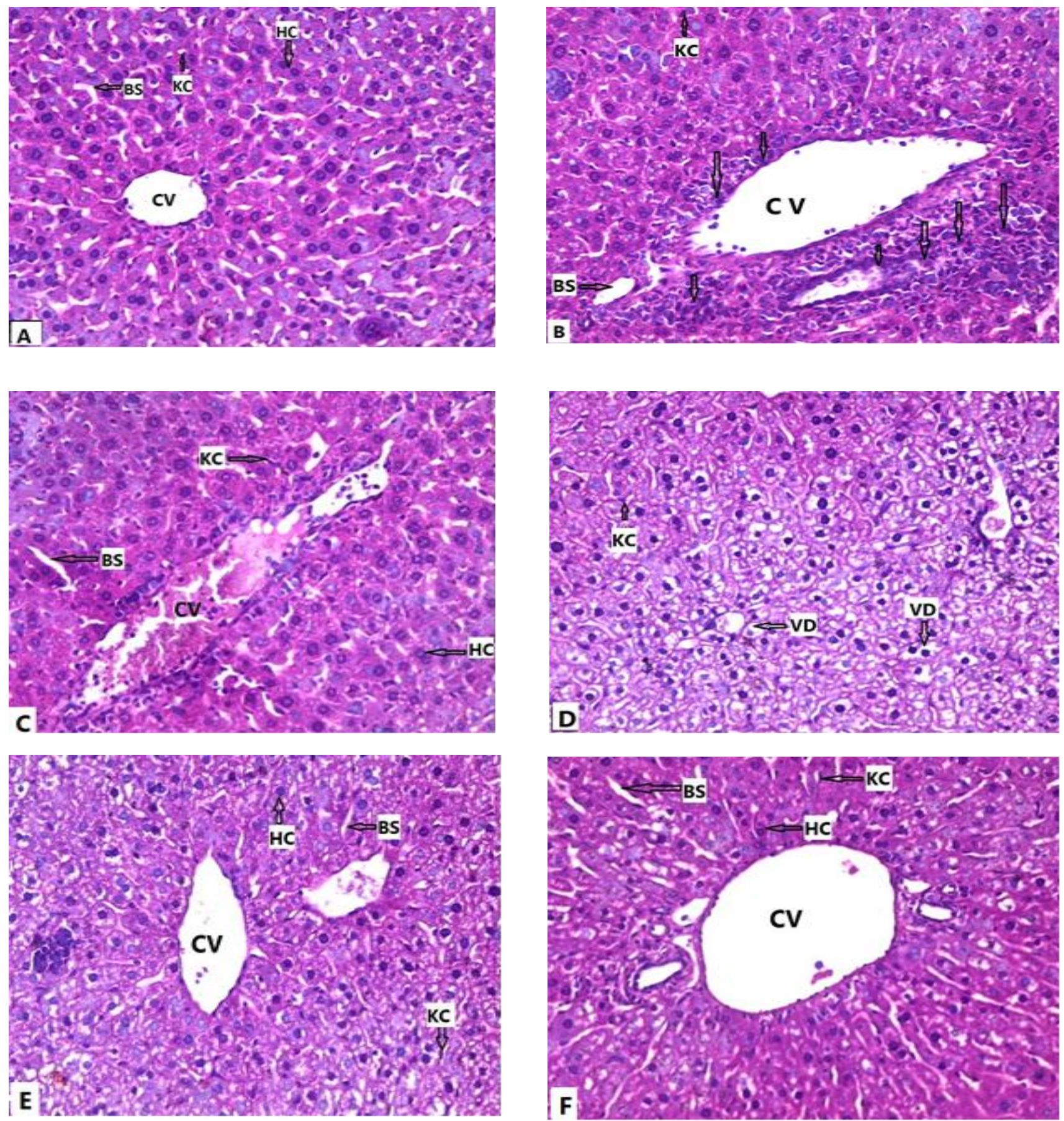

Figure 2. Photomicrograph of histological structure of control mice liver (A) showing normal histological appearance of liver including central vein (CV), blood sinusoids (BS), hepatic cells (HE) and Kupffer cells (KC) and histological structure of liver in tumor mice group (B, C, D) showing enlarged and congested central vein (CV), enlarged blood sinusoids (BS), infiltration of tumor cells and leukocytes (arrows) and cytoplasmic vacuolar degeneration (VD). Histological structure of liver mice treated with ginger; showing normal histological appearance (E). Liver of mice bearing tumor treated with ginger showing different ameliorations in the hepatic structure (F) with enlarged central vein (CV). (H\&E, X400). 

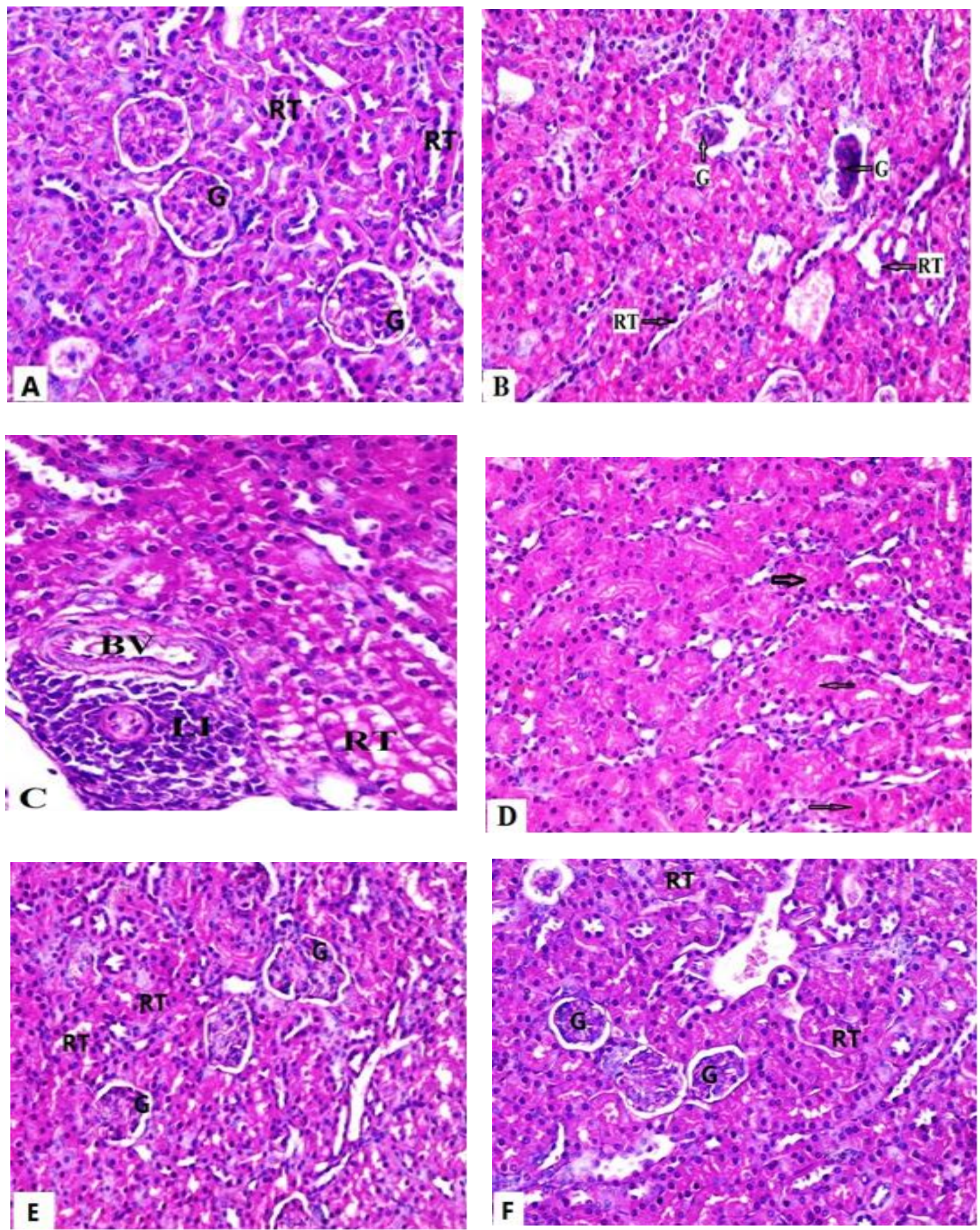

Figure 3. Photomicrograph of histological structure of kidney of a control mouse (A) showing normal glomeruli (G) and normal renal tubules (RT). Mice treated with EAC showed a glomerulus atrophy and degenerated renal tubules (B); Leucocytic infiltration (LI) and degenerated renal tubules (RT) are exhibited in figure (C); proteinaceous casts in the lumen of the renal tubules (arrows) are found in figure (D). Kidney cortex after ginger extract treatment showing normal glomeruli (G) and normal renal tubules (RT) figure (E). Kidney of mice treated with ginger in mice bearing tumors showing obvious ameliorations in the renal structure fig (F). H\&E, X400. 

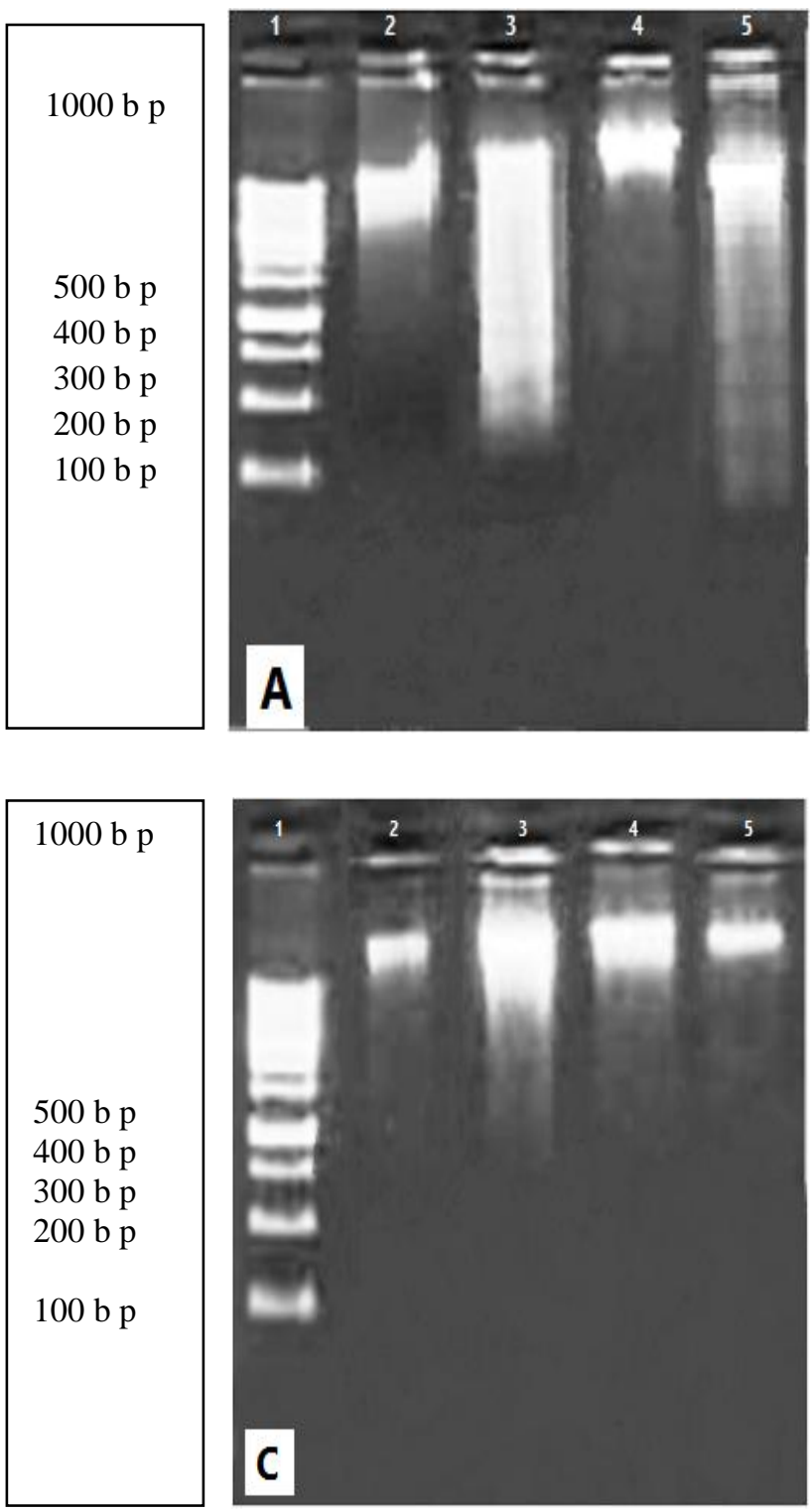

\section{Biochemical results:}

Effect of ginger extract on liver \& kidney functions

Data in table (2a) revealed that the values of Alanine Transaminase (ALT) estimated in the mice blood sera; exhibited an elevated values in tumor group compared with control $(\mathrm{P} \leq 0.0001)$. The mice treated with ginger showed an inhibition in the values of (ALT) to be only in a very significant change ( $\mathrm{P} \leq$ 0.01 ) in relation to control values. On the other hand, the recorded values of (ALT) was still very extremely significant change $(P \leq 0.0001)$ when compared with control; in tumor groups treated with ginger although the recorded values was reduced.

Data in table (2a) revealed that the values of Asparate Transaminase (AST) was also estimated in the mice

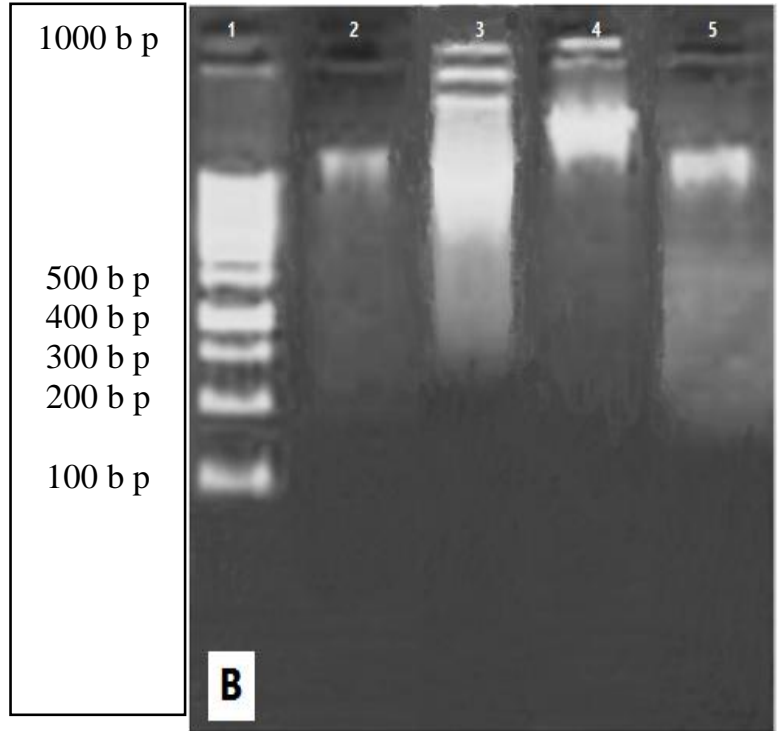

Figure 4. Gel electrophoresis of tumor genomic DNA (A), liver genomic DNA (B) and kidney genomic DNA (C) in different animal groups. Lane 1: DNA Ladder, Lane 2: Control, Lane 3: Tumor, Lane 4: Ginger and Lane 5: Ginger + Tumor.

blood sera; and showed an elevated values in tumor group compared with control $(\mathrm{P} \leq 0.0001)$; very extremely significant change. The mice treated with ginger leads to an inhibition in the values of (ALT) to be only a significant change $(\mathrm{P} \leq 0.05)$ in relation to control values. On the other hand, the recorded values of (ALT) was still very extremely significant change $(\mathrm{P} \leq 0.0001)$ when compared with control; in tumor groups treated with ginger although the recorded values was reduced.

Data in table (2b) revealed that the values of urea recorded an extremely significant elevation $(\mathrm{P} \leq$ 0.001) in the sera of tumor group mice compared to control group. The mice treated with ginger leads to a significantly decreasing in the values of urea $(\mathrm{P} \leq$ 0.05 ) in relation to control values. On the other hand, the recorded values of urea was decreased in mice bearing solid tumors treated with ginger from extremely significant $(\mathrm{P} \leq 0.001)$ to very significant $(P \leq 0.01)$ to be near of control values.

Data in table (2b) detected that the values of creatinine recorded a very significant elevation $(\mathrm{P} \leq$ 0.01 ) in the sera of tumor group mice compared to control group. In relation to the mice treated with ginger; the recorded values of creatinine was 
significantly reduced $(\mathrm{P} \leq 0.05)$ compared with and CAT) to record significant change $(\mathrm{P} \leq 0.05)$ and control. On the other hand, the recorded values of non-significant $(\mathrm{P}>0.05)$ change respectively when creatinine in mice - bearing solid tumors treated with compared to control values in relation to ginger. On ginger was still in a very significant elevation $(\mathrm{P} \leq$ the other hand, the recorded values of both SOD and 0.01) in relation to control group.

CAT was elevated from very extremely significant (P $\leq 0.0001)$ to very significant change $(\mathrm{P} \leq 0.01)$ in Table (2a,b): Effects of ginger extract on liver and tumor mice treated with ginger; when compared to kidney functions in different animal groups. control.

(a)

Table (3): Effects of ginger extract on MDA, SOD

\begin{tabular}{|c|c|c|}
\hline Groups & ALT (U/L) & AST (U/L) \\
\hline Control & $15.67 \pm 0.5774$ & $16.00 \pm 2.000$ \\
\hline Tumor & $88.67 \pm 2.517^{* * * *}$ & $92.00 \pm 1.000^{* * * *}$ \\
\hline Ginger & $21.67 \pm 1.155^{* *}$ & $22.33 \pm 3.215^{*}$ \\
\hline $\begin{array}{c}\text { Ginger } \\
\text { +Tumor }\end{array}$ & $34.33 \pm 0.5774^{* * * *}$ & $34.00 \pm 1.000^{* * *}$ \\
\hline
\end{tabular}

(b) and CAT activities in different groups.

\begin{tabular}{|c|c|c|}
\hline Groups & UREA (mg/dl) & $\begin{array}{c}\text { Creatinine } \\
\text { (mg/dl) }\end{array}$ \\
\hline Control & $14.00 \pm 1.000$ & $0.4000 \pm 0.1000$ \\
\hline Tumor & $29.33 \pm 1.528^{* * *}$ & $0.8667 \pm 0.05774^{* *}$ \\
\hline Ginger & $17.00 \pm 1.000^{*}$ & $0.6000 \pm 0.0^{*}$ \\
\hline $\begin{array}{c}\text { Ginger }+ \\
\text { Tumor }\end{array}$ & $25.00 \pm 1.732^{* *}$ & $0.8000 \pm 0.0^{* *}$ \\
\hline
\end{tabular}

\begin{tabular}{c|c|c|c|}
\hline Groups & \multicolumn{1}{|c|}{ MDA (nmol/g) } & \multicolumn{1}{|c|}{ SOD (U/g) } & \multicolumn{1}{|c|}{ CAT (U/g) } \\
\hline Control & $4.058 \pm 0.00557$ & $62.57 \pm 0.5831$ & $29.00 \pm 1.000$ \\
\hline Tumor & $10.96 \pm 0.2770^{* * * *}$ & $30.64 \pm 1.704^{* * * *}$ & $12.33 \pm 1.528^{* * * *}$ \\
\hline Ginger & $4.248 \pm 0.1243^{\$}$ & $60.48 \pm 0.9778^{* *}$ & $26.33 \pm 1.528^{\$}$ \\
\hline $\begin{array}{c}\text { Ginger } \\
+ \\
\text { Tumor }\end{array}$ & $4.519 \pm 0.1060^{* *}$ & $57.00 \pm 1.556^{* *}$ & $22.33 \pm 1.528^{* *}$ \\
\hline
\end{tabular}

All data are expressed as mean \pm SD.

$(* * * *)$ very extremely significant $\mathrm{P} \leq 0.0001$

(***) extremely significant $\quad \mathrm{P} \leq 0.001$

(**) very significant $\quad \mathrm{P} \leq 0.01$

(*) significant $\quad \mathrm{P} \leq 0.05$

(\$) not-significant $\quad \mathrm{P}>0.05$

\section{Discussion}

Effect of ginger extract on oxidative and antioxidant enzymes

The recorded data in (Table 3) revealed that there was very extremely significant $(\mathrm{P} \leq 0.0001)$ increase in the level of MAD in sera of mice -bearing solid tumors compared to control group. Mice treated with ginger showed a non-significant decrease of the MDA level $(P>0.05)$ when compared to control group to be near to normal values. Ginger induced inhibition in the levels of MAD in tumor groups from very extremely significant change $(\mathrm{P} \leq 0.0001)$ to only very significant change $(\mathrm{P} \leq 0.01)$ when compared to control group. There was an effective inhibition in the levels of MDA between the tested groups compared to control.

The recorded data in (Table 3) showed a very extremely significant $(P \leq 0.0001)$ decrease in the levels of SOD and CAT in mice - bearing solid tumors when compared to control group. Mice treated with ginger leads to nearly normal values of (SOD
The basic target in the use of anti-cancer agents is to inhibit the propagation of tumor cells or destroy them without damaging the normal cells. The use of natural products is considered one of the most effective methods used for cancer treatment; with low toxicity than chemotherapy and radioactive treatment (Reddy et al., 2003). Many natural products have been studied for anti-cancer activity on various experimental models (Abd El-Wahab and Fouda, 2009).

Ginger has long been used in traditional medicine for treatment of different diseases (Hanafy, 2010). Ginger contains active phenolic compounds such as gingerol, paradol and shogoal that have antioxidant (Jeyakumar et al., 1999), anti-inflammatory (Hudson et al., 2006), anti-cancer (Shukla and Singh 2007) and antiangiogenesis (Huang et al., 2000).

The results of this study reported that ginger extract inhibited the growth of tumor volume significantly and this is agreed with (Kottarapat et al., 2015) who 
mentioned that the ginger essential oil induced reduction in the tumor volume.

Results of the present study revealed that EAC induced hepatotoxicity in treated mice. These hepatotoxic effects are characterized by many histopathological alterations and elevation of serum level of ALT and AST. This finding was approved by Abou Zaid et al., (2011). The liver sections of the EAC-inoculated animals, showed enlarged and congested central vein, enlarged blood sinusoids, leucocytic infiltration and cytoplasmic vacuolar degeneration. This finding was in agreement with (Bhattacharyya et al., 2007; Chakraborty et al., 2007). In experimental Ehrlich ascites carcinoma treated with ginger; the normal liver architecture was restored; nearly normal histological structure with slight congested and enlarged blood vessels was observed, this finding was confirmed with (EIGhonaimy, 2015) who discussed the role of ginger against the hepatotoxicity of metalaxyl.

Serum urea and creatinine levels was elevated elevation in mice of EAC-bearing tumors. This means renal dysfunction. A very highly significant increase in serum urea concentration in tumor-bearing female mice was confirmed by the results observed by (Abou Zaid et al., 2011) and (Hussein and Azab 1997); who found a highly significant increase in plasma urea concentration in tumor-bearing mice. It was attributed such increase in blood urea concentration to catabolic effect of tumor and the increase in urea production. Also, a very significant increase in serum creatinine concentration in tumor bearing mice was reported by Hussein (2003). The present results showed that ginger administration caused significant decrease in the values of serum urea and creatinine. This finding is in agreement with Mehrdad et al., (2011).

Kidney sections of EAC-inoculated animals showed glomerulus atrophy, degenerated renal tubules, leucocytic infiltration and proteinaceous casts in the lumen of the renal tubules. This result was in concomitance with (Abd El-Wahab and Fouda, 2009).

The renoprotective effect of ginger was studied by some investigators. Shanmugam et al., (2010) reported that ginger alleviated histopathological alterations in kidney of rats treated with alcohol. Ajith et al., (2007) demonstrated the role of ethanolic extraction of ginger in reducing the serum urea, and creatinine levels significantly and this an evidence of nephroprotection; this finding supports the results of this study.

Serum (MDA) showed a significant increase in EAC group. MDA is an important oxidative metabolite of polyunsaturated fatty acids, which consists of the biomembrane. MDA is often seen as an indicator of the oxidation status in cells or tissues. So, the high level of MDA is detrimental to cells and tissues, and leads to lose of their normal bio-function (Cheng et al., 2011). SOD and CAT showed a very significant decrease in EAC group. A decrease in SOD activity in EAC bearing mice which might be due to loss of $\mathrm{Mn}^{+2}$ SOD activity in EAC cells and the loss of mitochondria leading to a decrease in total SOD activity in the liver (Sun et al., 1989).

Abd El-Aziz et al. (2014) showed that the Serum malondialdehyde (MDA) recorded a significant increase in Ehrlich group; but the recorded values of Serum superoxide dismutase (SOD) and Serum catalase (CAT) showed a very significant decrease in Ehrlich group. This finding is agreed with the results of this study.

It was obtained in this study that ginger increased the activities of the antioxidant enzymes (superoxide dismutase and catalase) and reduced level of malondialdhyde. This result was in agreement with the results of (Amin and Hamza, 2006; Sakr et al., 2011) who mentioned that ginger contains a higher content of flavonoids with high antioxidant activity. The inhibition of peroxidative damage evidenced by reduced MDA level and the elevation of catalase and SOD activities in the ginger-mice groups was also in concomitance with previous findings concluded that the ginger significantly lowered lipid peroxidation (Morakinyo et al., 2008) by maintaining the activities of the antioxidant enzymes; SOD and CAT in the rat testes (Ahmed et al., 2002).

The mice subcutaneously inoculated with Ehrlich ascites cells showed a marked DNA fragmentation. However mice treated with ginger leads to a highly decreased in EAC induced DNA fragmentation to be near to normal pattern. This finding was in agreement with (Hanafy, 2009) who mentioned the same results of this work.

\section{Conclusion:}

Ehrlich ascites carcinoma (EAC) has a powerful harmful effects on all parameters investigated in this study; EAC induced increasing in the tumor volume significantly, increased the levels of liver function 
enzymes (ALT \& AST), kidney function enzymes (urea \& creatinine) and the oxidant enzyme Malondialdhyde (MAD) significantly. On the other hand, EAC reduced the levels of antioxidant enzymes; Superoxide Dismutase (SOD) and Catalase (CAT) significantly and caused detrimental histopathological effects to the liver and kidney. Finally, EAC induced DNA fragmentation. Ginger extract in mice-bearing solid tumors; modulated the levels of (ALT, AST, urea, creatinine, MDA, SOD and CAT) significantly to be near of normal values. Ginger extract also induced recovery in the histological structures of both liver and kidney, it also restored the normal pattern of DNA. Ginger extract has no bad effects on control mice.

\section{References}

Abd El-Aziz A.F., M.E. Hefni and Amira M. Shalaby (2014). Inhibitory effects of Rosemary (Rosmarinus officinalis L.) on Ehrlich ascites carcinoma in mice. Int. J. Curr. Res. Aca. Rev; 2(9):330-357.

Abd El-Wahab M Samia and Fouda M Fatma (2009). Histological and histochemical study on the effect of Ehrlich ascites carcinoma on the liver and kidney of mice and the possible protective role of tetrodotoxin. Egyptian Journal of Biology, 11:13-25.

Abou Zaid A.R. Omayma, Mohammed R.R. Hassanein, Yakout A. EL-Senosi, Mohammed F. EL-Shiekha (2011). Ameliorative effect of curcumin and tannic acid on tumorinduced in female mice. Benha Veterinary Medical J., 1:6169.

Ahmed RS, Seth V, Banerjee BD. (2000). Influence of dietary ginger on antioxidant defence system in rat: comparison with ascorbic acid. Ind $\mathrm{J}$ Exp Biol. 38:604- 606.

Aktas E (1996). Ehrlich Ascit Sivisinin LHücrelerinin Çoğalma Hızına Etkisi. Yüksek Lisans Tezi. İstanbul Üniversitesi Fen Bilimleri Enstitüsü. İstanbul. Anabilim Dalı. İstanbul.

Ali A. Doaa, Badr El-Din K. Nariman, Abou-Elmagd F. Rania (2015). Antioxidant and hepatoprotective activities of grape seeds and skin against Ehrlich solid tumor induced oxidative stress in mice. Egypt. J. basic and applied Sciences (2) 98-109.

Amin A, Hamza, AA. (2006). Effects of Rosell and ginger on cisplatin- induced reproductive toxicity in rats. Asian J. Androl. 8(5): 607-612.
Armitage, P. \& Berry, G. (1987). In: Statistical Methods in Medical Research, Armitage, P. and Berry, G. (Eds.). pp. 186-00, Oxford: Blackwell Scientific Publications.

Banchroft, J.D., Stevens, A. and Turner, D.R. (1996). Theory and practice Of Histological Techniques. Fourth Ed. Churchil Livingstone, New York, London, San Francisco, Tokyo.

Bhattacharyya A, Mandal D, Lahiry L, Bhattacharyya S, Chattopadhyay S, Ghosh UK, Sa G \& Das $\mathrm{T}(2007)$. Black tea-induced amelioration of hepatic oxidative stress through antioxidative activity in EAC-bearing mice. J. Environmental Pathology Toxicology \& Oncology 26 (4): 245-254.

Chakraborty T, Bhuniya D, Chatterjee M, Rahaman M, Singha D, Chatterjee BN, Datta S, Rana A, Samanta K,Srivastawa S, Maitra S K \& Chatterjee $M$ (2007). Acanthus ilicifolius plant extract prevents DNA alteration in a transplantable Ehrlich ascites carcinoma- bearing murine model. World J. Gastroenterology 13 (48): 6538-6548.

Cheng J, Wang F, Yu DF, Wu PF, Chen JG (2011). The cytotoxic mechanism of malondialdehyde and protective effect of carnosine via protein cross linking/mitochondrial dysfunction/reactive oxygen species/MAPK pathway in neurons. Eur. J. Pharmacol. 650(1): 184-194.

Diwanay S, Chitre D and Patwardhan B. (2004). Immunoprotection by botanical drugs in cancer chemotherapy. J Eth pharmacol.; 90(1): 49-55.

Draper HH, Hadley M. (1990). Malondialdehyde determination as index of lipid peroxidation. Methods Enzymol; 186:421-431.

Ehrlich P, Apolant H (1905). Beobachtungen ÜberMaligne Mausentumoren. Berlin. Klin. Wschr. 28: 871-874.

EI-Ghonaimy M. Nabila (2015). Role of ginger (Zingiber officinale) against metalaxyl induced hepatotoxicity in male albino rats: a histological and immunohistochemical study. Journal of Histology \& Histopathology; 2(9): doi: 10.7243/2055-091X-2-9.

El-Merzabani MM, El-Aaser AA, Attia MAM, ElDuweini AK, Ghazal AH (1979). Screening system for Egyptian Plants with Potential Antitumor Activity.J.Planta Medica.36:150-155. 
Evans, W.C.,

(2002). Trease and Evans Pharmacognosy. Reed Elsevier India Pvt. Ltd., pp: 394.

Fouda FM (2005). Anti-tumor activity of tetrodotoxin extracted from the Masked Puffer fish Arothron diadematus. Egyptian J.Biology 7: 1-13.

Gonenc A, Erten D, Aslan S, Akinci M, Simşek B, Torun M. (2006). Lipid peroxidation and antioxidant status in blood and tissue of malignant breast tumor and benign beast disease. Cell Biol Int; 30:376-380.

Gothoskar, S. V., \& Ranadive, K. J. (1971). Anticancer screening of SAN-AB: an extract of marking nut Semicarpus anacardium. Indian $\mathrm{J}$. Experimental Biology, 9, 372-375.

Hanafy E. Zeinab (2009). Ginger extract Antimutagens as Cancer Chemopreventive Agent against Ehrlich Ascites Carcinoma. Academic J. Cancer Research; 2(2): 61-67.

Hanafy E. Zeinab (2010). Cytogenetics Changes on Cancer Cells as Affected by Ginger Extracts. J.American Science. ; 6 (8): 525-539.

Hashim YZ, Phirdaous A, Azura A. (2014). Screening of anticancer activity from agarwood essential oil. Pharmacognosy Res.; 6: 191-194.

Huang, S.; DeGuzman, A.; Bucana, C.D.and Fidler, I. J. (2000). Nuclear factor-kappaB activity correlates with growth, angiogenesis, and metastasis of human melanoma cells in nude mice. Clin Cancer Res. 6:2573-2581.

Hudson, E.A.; Fox, L.H.; Luckett, J.C.A. and Manson, M.M. (2006). Ex vivo cancer chemoprevention research possibilities. Environmental Toxicology and pharmacology, 21:204-14. 32.

Hussein, S.A. (2003). Clinical biochemistry interpretation and applications. First Edition (Text Book).

Hussein, S.A., Azab, M.E. (1997). Effect of insulin treatment on some metabolic changes on experimentally induced tumor in female mice. The Egyptian J. Biochemistry 15: 61- 80.

Jeyakumar, S.M.; Nalini. N. and Menon, V.P. (1999). Antioxidant activity of ginger (Zingiber officinale) in rats fed a high fat diet. Medical Sciences Research, 27:341- 344.
Jia, L.- J., Xu, H.- M., Ma. D.- Y., Hu, Q.- G., Huang, X.- F., Jiang, W.- H., Li, S.- F., Jia, K.- Z., Huang, Q.- L. \& Hua, Z.- C. (2005). Enhanced Therapeutic Effect by Combination of TumorTargeting Salmonella and Endostatin in Murine Melanoma Model, Cancer Biol. Ther,4, 840-845.

Kottarapat jeena, vijayasteltar b liju, ramadasan kuttan (2015). Antitumor and cytotoxic activity of ginger essential oil (zingiber officinale roscoe). Int $\mathrm{J}$ Pharm Pharm Sci, Vol 7, Issue 8, 341-344.

Kundu, J.K., H.K. Na and Y.J. Surh, (2009). Ginger derived phenolic substances with cancer preventive and therapeutic potential. Forum Nutr, 61: 182-192.

Loewenthal H, Jahn G (1932). bertragung - Suersuche Mit Carcinomatöser MauseAsciteslussigleit Und İhr Verhalten Gegen Physikalische Und Chemische Einwirkungen. Z. Krebsforsch. 37: 439-447.

Mahadik, S.P. and Scheffer, R.E. (1996). Oxidative injury and potential use of antioxidant in schizophrenia. Prostaglandin, leukot Essent Fatty acid: 55; 45-54.

Mehrdad Modaresi1, Mozhgan Ghobadi Pour, Sayed Ali Tabeidian1, Alireza Jalalizand (2011). Study of Histopathologic changes of the effect of Zingiber extract on mice kidneys. IPCBEE vol.9: 1620.

Morakinyo AO, Adeniyi OS, Arikawe AP. (2008). Effects of Zingiber officinale on reproductive functions in male rats. Afr J Biomed Res. 11(3):329333.

Purshotam Kaushik, Pankaj Goyal (2011). Evaluation of Various Crude Extracts of Zingiber officinale Rhizome for Potential Antibacterial Activity: A Study in Vitro. Advances in Microbiology; 1: 7-12.

Reddy L1, Odhav B, Bhoola KD (2003). Natural products for cancer prevention: a global perspective. Pharmacol Ther.; 99(1):1-13.

Sahdeo Prasad and Amit K. Tyagi (2015). Ginger and Its Constituents: Role in Prevention and Treatment of Gastrointestinal Cancer. Gastroenterology Research and Practice. http://dx.doi.org/10.1155/2015/142979. 
Sakr,S.A. ,Lamfon H.A., essawy,A.E. (2011). Ginger (Zingiber officinale ) extract ameliorates metalaxyl fungicide induced nephrotoxicity in albino mice. Afr. J. Pharm. Pharmacol . 5(2): 104-112. 28.

Shanmugam KR, Ramakrishna CH, Mallikarjuna K, Reddy KS (2010). Protective effect of ginger against alcohol-induced renal damage and antioxidant enzymes in male albino rats. Indian J Exp. Biol.; 48(2):143-149.

Shukla Y, Prasad S, Tripathi C, Singh M, George J, Kalra N (2007). In vitro and in vivo modulation of testosterone mediated alterations in apoptosis related proteins by [6]-gingerol. Mol Nutr Food Res, 51:1492-1502.

Shukla, Y. and Singh, M. (2007). Cancer preventive properties of ginger: A brief review. Food and Chemical Toxicology, 45:683-690.

Stewart, B.S. and P. Kleihues, (2003). Cancers of female reproductive tract. In: World Cancer Report. World Health Organization, International Agency for Research in Cancer, IARC Press.

Sun, Y., L.W. Oberley, J.H. Elwell, R.E. Sierra RE, (1989). Antioxidant enzyme activities in normal and transformed mice liver cells. Intern J Can; 44: 1028-1033.

Surh, Y.J., (2002). Anti-tumor promoting potential of selected spice ingredients with antioxidative and anti-inflammatory activities: a short review. Food and Chemical Toxicology; 40: 1091-1097.

Taskın Ei (2002). Ehrlich Ascites Tümörü ile Balb-C Farelerde Oluşturulmuş Solid Tümör Modelinde Curcuminin Apoptoz Üzerine Etkileri. İstanbul Üniversitesi Sağlık Bilimleri Enstitüsü Tıbbi Biyoloji.
Tatiane De Rossi, Vanessa Jacob Victorino, Lucas Freitas de Freitas, Ana Cristina da Silva do Amaral Herrera; Rubens Cecchini. Breast (2009). Cancer and Oxidative Stress in Chemotherapy. Applied Cancer Research; 29(4), 150-156.

Tayeb K, William TB. (1999). Merbarone, a catalytic inhibitor of DNA topoisomerase II, induces apoptosis in CEM cells through activation of ICE/CED-3-like protease. Mol Pharmacol; 55: 548456.

Topic B, Tani E, Tsiakitzis K, Kourounakis P N, Dere E, Hasenohrl R U, Hacker R, Mattern C M, and Huston J P. (2002). Enhanced maze performance and reduced oxidative stress by combined extracts of Zingiber officinale and gingko biloba in the aged rat. Neurobiol. of Aging. 23: 135-143.

Woolliams JA,Wiener G, Anderson PH, McMurray CH. (1983). Variation in the activities of glutathione peroxidase and superoxide dismutase and in the concentration of copper in the blood in various breed crosses of sheep. Res Vet Sci; 34:69—77.

Yogeshwer Shukla, Madhulika Singh (2007). Cancer preventive properties of ginger: A brief review. Food and Chemical Toxicology. Volume 45, Issue 5, Pages: 683-690. 